\title{
Role of diffusional coherency strain theory in the discontinuous precipitation in $\mathrm{Mg}-\mathrm{Al}$ alloy
}

\author{
K T KASHYAP*, C RAMACHANDRA, M SUJATHA and B CHATTERJI \\ Central Materials and Processes Laboratory, Foundry \& Forge Division, Hindustan Aeronautics Ltd., Bangalore 560017, \\ India
}

MS received 24 August 1999; revised 13 January 2000

\begin{abstract}
Discontinuous precipitation (DP) occurs in many alloy systems under certain conditions. It is called discontinuous precipitation because precipitation occurs on prior matrix grain boundaries followed by grain boundary movement. The DP nodule consists of alternate lamellae of the precipitate and the matrix respectively. The chemical driving force for DP is one of solute supersaturation. Although solute supersaturation is responsible for precipitation, it has to be coupled with another driving force to explain grain boundary migration. This coupling driving force has been identified to be diffusional coherency strain which has been verified to be active in diffusion induced grain boundary migration and liquid film migration.

To test diffusional coherency strain theory for discontinuous precipitation Mg-7Al and Mg-7Al-1Pb alloys were studied. While the fraction transformed was high at $6 \%$ in $\mathrm{Mg}-7 \mathrm{Al}$ alloy, it was significantly low at $2 \%$ in $\mathrm{Mg}-7 \mathrm{Al}-1 \mathrm{~Pb}$ alloy. The velocity of $\mathrm{DP}$ nodules decreased by half in alloy with $\mathrm{Pb}$ as compared to the alloy without $\mathrm{Pb}$. Theoretical calculations also predict that the misfit parameter $\delta_{\text {th }}$ decreases with the addition of $\mathrm{Pb}$. These observations are an evidence to the fact that diffusional coherency strain is the most active driving force for the movement of the grain boundaries of the DP nodules during discontinuous precipitation in $\mathrm{Mg}-\mathrm{Al}$ alloy.
\end{abstract}

Keywords. DP; Mg-Al alloy; Mg-7Al-1Pb alloy; DIGM; LFM.

\section{Introduction}

Diffusion induced grain boundary migration (DIGM) was first isolated by Hillert and Purdy (1978) in their classic experiments on iron subjected to a zinc vapour source wherein grain boundaries migrated leaving behind a solid solution of Fe-Zn. They attributed the driving force for DIGM to be that of free energy of mixing. Baluffi and Cahn (1981) pointed out that both alloying and dealloying can occur during DIGM and that the chemical driving force (free energy of mixing) had to be coupled with another driving force explaining grain boundary migration. The coupling driving force was attributed to the diffusing species having different grain boundary diffusion coefficients.

Yoon and Hupman (1981) in their studies on liquid film migration (LFM) in $\mathrm{W}-\mathrm{Ni}$ system attributed the driving force for liquid film migration to be diffusional coherency strain. Baik and Yoon (1986) showed LFM in a Mo-Ni system with low Fe additions and showed that diffusional coherency strain model could explain the boundary migration. They proposed that the coherency strain arose because of a thin diffusion layer ahead of the migrating boundary. Rhee et al (1987) showed in Mo-Ni-(Co-Sn)

\footnotetext{
*Author for correspondence
}

alloy that when Co and Sn were raised in the liquid film, strain energy could be raised from positive to negative and when strain energy was zero, LFM and grain boundary migration stopped although the free energy of mixing was finite. Thus the driving force for LFM was shown to be that of diffusional coherency strain which could also explain grain boundary migration during DIGM.

The same theoretical problem exists for discontinuous precipitation where the supersaturated matrix decomposes into cells (nodules) which has alternate lamellae of the precipitate and depleted matrix. Fournelle and Clark (1972) have studied the origins of cellular precipitation (discontinuous precipitation) in $\mathrm{Cu}-\mathrm{In}$ system. However, they have not pointed out the nature of driving force for grain boundary migration during discontinuous precipitation. Hillert (1983) has suggested that diffusional coherency strain to be the driving force for DP in $\mathrm{Cu}-\mathrm{Cd}$ system. Recently, Chung et al (1992) carried out experiments on $\mathrm{Al}-21.8$ at.\% $\mathrm{Zn}$ and showed by rigorous mathematical/quantitative analysis that diffusional coherency strain hypothesis worked for discontinuous precipitation.

However, Meyrick (1976) has argued that for alloys in which solute tends to segregate to grain boundaries thereby effectively reducing the grain boundary energy, diminution in the segregated population due to precipitation can provide a driving force for the boundary to migrate. Under these circumstances, it becomes necessary 
to ascertain the underlying mechanism for discontinuous precipitation in $\mathrm{Mg}-\mathrm{Al}$ system. If diffusional coherency theory is the mechanism, addition of $\mathrm{Pb}$ to the $\mathrm{Mg}-\mathrm{Al}$ alloy should cause reduction in coherency strains and thus negate DP. On the other hand, if Meyrick's hypothesis is valid, it should not have any influence on DP. Thus in this way, it becomes a novel, direct and critical test to understand the mechanism for DP unlike the indirect tests of applying external stress tried by Chung et al (1992).

\section{Experimental}

The $\mathrm{Mg}-\mathrm{Al}$ alloy was melted and cast in the Directorate of Technical Development (DTD) test bars in sand molds. In another melt, $1 \mathrm{wt} \%$ lead was added to the melt $(\mathrm{Mg}-$ Al alloy) and cast as DTD test bars. The chemical compositions of both the alloys are shown in table 1 .

The test bars were sectioned into small pieces and solutionized at $633 \mathrm{~K}$ for $24 \mathrm{~h}$ and water quenched. Subsequently, the samples were aged at $523 \mathrm{~K}$ for $2 \mathrm{~h}$ and $4 \mathrm{~h}$, respectively.

The samples were mechanically polished by conventional methods and etched in citric acid solution. Then the samples were analysed for discontinuous precipitation

Table 1. Chemical composition of alloys (wt $\%$ ).

\begin{tabular}{lccccc}
\hline Sl. no. & Aluminium & Zinc & Manganese & Lead & $\begin{array}{c}\text { Density } \\
\text { (g/cc) }\end{array}$ \\
\hline Alloy A & 7.00 & 0.65 & 0.22 & - & 1.7999 \\
Alloy B & 7.05 & 0.64 & 0.24 & 0.91 & 1.8060 \\
\hline
\end{tabular}

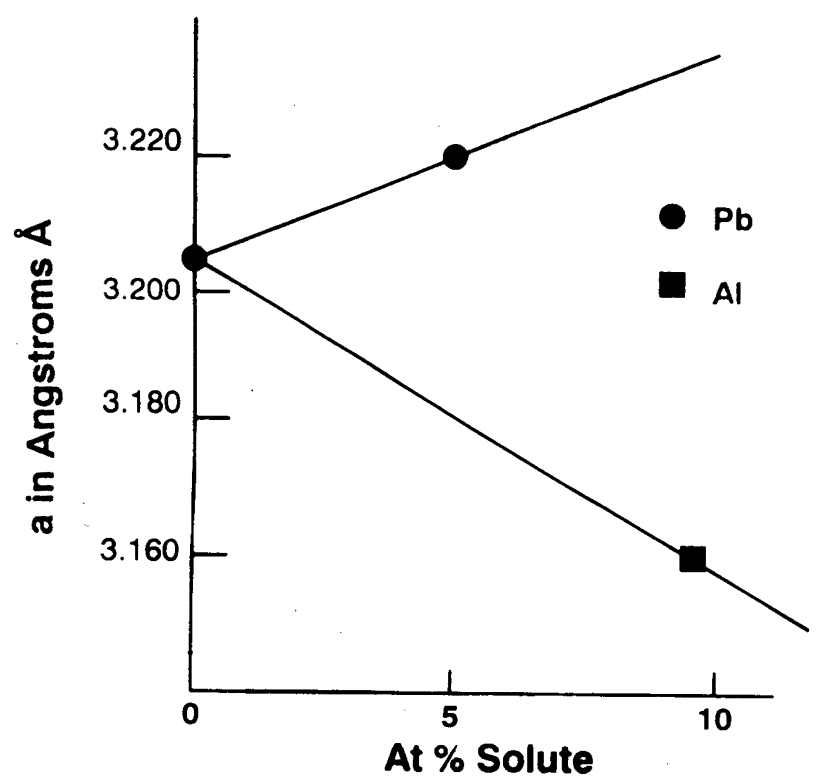

Figure 1. Effect of $\mathrm{Al}$ and $\mathrm{Pb}$ on lattice parameter ' $a$ ' of $\mathrm{Mg}$. using a Nikon Epiphot Metallurgical Microscope. Volume fraction transformed was determined by image analysis.

Samples (with $1 \% \mathrm{~Pb}$ and without $\mathrm{Pb}$ ) were aged at $523 \mathrm{~K}$ for $72 \mathrm{~h}$ to produce a large volume fraction transformed and subjected to X-ray diffraction on a highresolution X-ray diffractometer.

\section{Results and discussion}

\subsection{Proposition on the effect of $\mathrm{Pb}$ on discontinuous precipitation}

It is known from literature (Smithels Metals Reference Book 1983), that $\mathrm{Pb}$ has a large solubility in magnesium. The maximum solid solubility of $\mathrm{Pb}$ in $\mathrm{Mg}$ is $45 \mathrm{wt} \%$ at $468 \mathrm{~K}$. It is also known (Pearson 1958) that while $\mathrm{Pb}$ increases the lattice parameters $a$ and $c$ of $\mathrm{Mg}, \mathrm{Al}$ reduces them. Figure 1 shows the effect of $\mathrm{Pb}$ and $\mathrm{Al}$ on lattice parameter ' $a$ ' and figure 2 on lattice parameter ' $c$ ' of magnesium. Thus if diffusional coherency strain is the driving force for discontinuous precipitation, the additions of $\mathrm{Pb}$ to $\mathrm{Mg}-\mathrm{Al}$ alloy where $\mathrm{DP}$ observed should be reduced. If Meyrick's hypothesis is valid, then the addition of $\mathrm{Pb}$ to $\mathrm{Mg}-\mathrm{Al}$ alloy should not affect $\mathrm{DP}$.

\subsection{Discontinuous precipitation and volume fraction determination}

Figures 3 and 4 show the microstructures of $\mathrm{Mg}-\mathrm{Al}$ (without $\mathrm{Pb}$ ) alloy aged at $523 \mathrm{~K}$ for $2 \mathrm{~h}$ and $4 \mathrm{~h}$ with DP

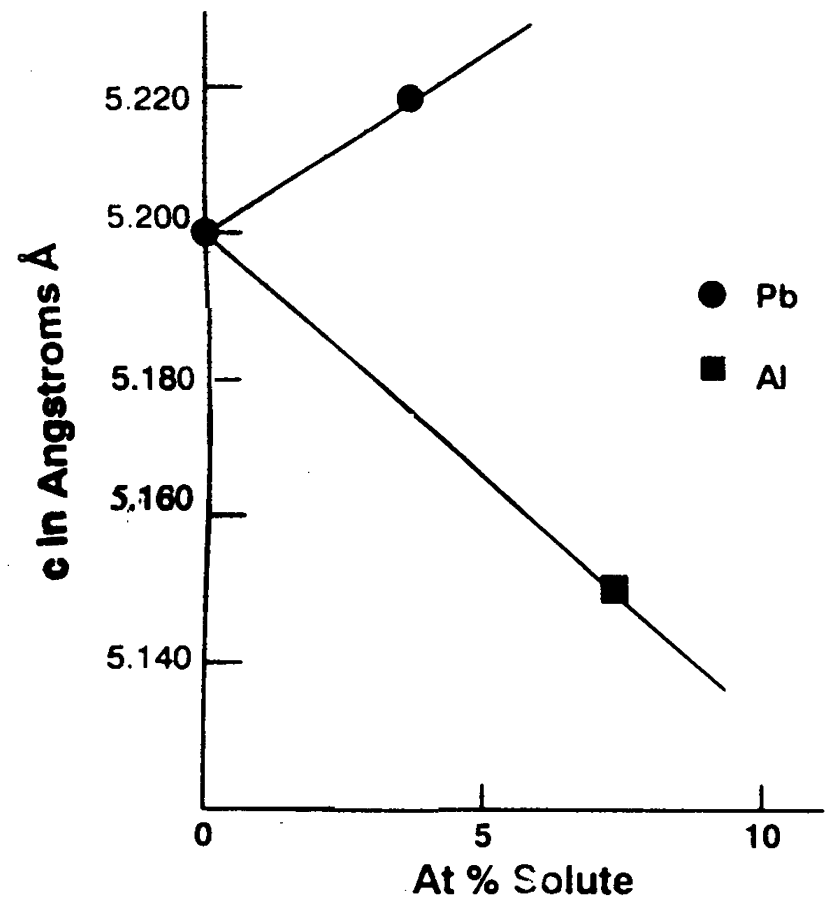

Figure 2. Effect of $\mathrm{Al}$ and $\mathrm{Pb}$ on lattice parameter ' $c$ ' of $\mathrm{Mg}$. 
nodule volume fraction of $5.4 \%$ and $6.8 \%$, respectively. Figures 5 and 6 show the microstructure of $\mathrm{Mg}-\mathrm{Al}$ (with $\mathrm{Pb}$ ) alloy aged at $523 \mathrm{~K}$ for $2 \mathrm{~h}$ and $4 \mathrm{~h}$ with DP nodule volume fraction of $2.36 \%$ and $2.96 \%$, respectively. On comparison of figures 3 and 5 and 4 and 6 , it can be stated that the fraction transformed in $\mathrm{Mg}-\mathrm{Al}$ alloy has decreased from $5.4 \%$ to $2.36 \%$ for $2 \mathrm{~h}$ aging and from $6.8 \%$ to $2.96 \%$ for $4 \mathrm{~h}$ aging, respectively on the addition of $\mathrm{Pb}$. Thus it is clearly seen that DP is suppressed with the addition of $\mathrm{Pb}$ in $\mathrm{Mg}-\mathrm{Al}$ alloy. Figures 7 and 8 show the X-ray diffraction patterns of the samples without $\mathrm{Pb}$ (figure $7 \mathrm{a}$ ) and with $0.9 \mathrm{wt} \% \mathrm{~Pb}$ (figure $7 \mathrm{~b}$ ), both aged at $523 \mathrm{~K}$ for $72 \mathrm{~h}$. It is seen that the precipitate in DP nodule is $\mathrm{Mg}_{17} \mathrm{Al}_{12}$ in both the cases. In figure 8, the intensity of the $\mathrm{Mg}_{17} \mathrm{Al}_{12}$ peaks is reduced and EDX results of table 3 also show 0.2 at. $\% \mathrm{~Pb}$ in the phase. From this it can be concluded that $\mathrm{Pb}$ disorders the ordered phase $\mathrm{Mg}_{17} \mathrm{Al}_{12}$ maintaining the same lattice parameters. From these results it can be seen that $\mathrm{Pb}$ does not alter the crystal structure of the phase.

\subsection{Growth velocity of DP nodules}

The velocity of DP nodule growth was determined by measuring the maximum nodule size divided by time. Table 2 shows the results of the velocity of DP nodule growth. It is clearly seen from the table that velocity has decreased to $2 \cdot 83 \AA$ sec from $6 \cdot 31 \AA$ sec on addition of $\mathrm{Pb}$ to $\mathrm{Mg}-\mathrm{Al}$ alloy at the end of $2 \mathrm{~h}$ aging. While in samples aged for $4 \mathrm{~h}$, the velocity has dropped to $2.47 \AA / \mathrm{sec}$ from $6 \cdot 375 \AA / \mathrm{sec}$ on addition of $\mathrm{Pb}$ to the alloy. This result clearly indicates that $\mathrm{Pb}$ addition has the effect of decreasing kinetics of DP growth in this alloy.

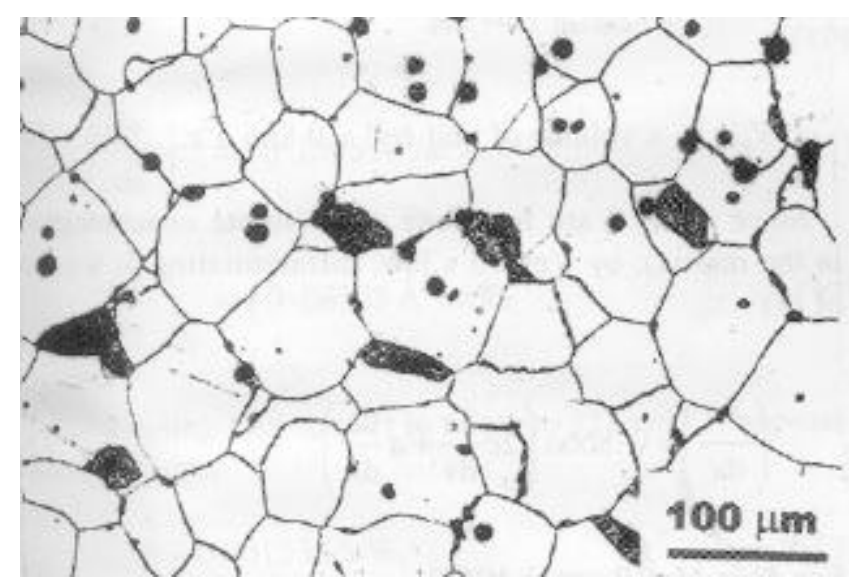

Figure 3. Microstructure of the $\mathrm{Mg}-\mathrm{Al}$ alloy without $\mathrm{Pb}$ showing DP nodules (aged at $523 \mathrm{~K}$ for $2 \mathrm{~h}$ ).

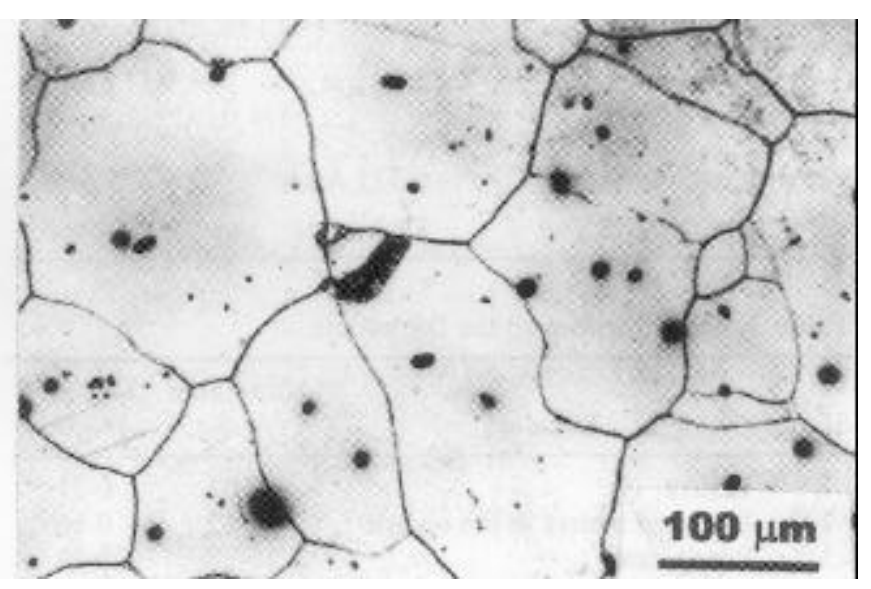

Figure 5. Microstructure of the $\mathrm{Mg}-\mathrm{Al}$ alloy with $\mathrm{Pb}$ showing insignificant DP nodules (aged at $523 \mathrm{~K}$ for $2 \mathrm{~h}$ ).

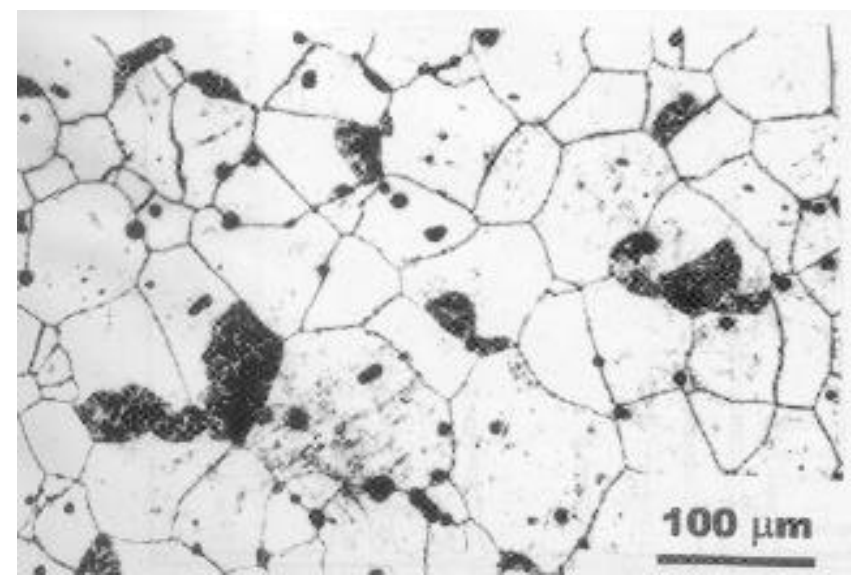

Figure 4. Microstructure of the $\mathrm{Mg}-\mathrm{Al}$ alloy without $\mathrm{Pb}$ showing DP nodules (aged at $523 \mathrm{~K}$ for $4 \mathrm{~h}$ ).

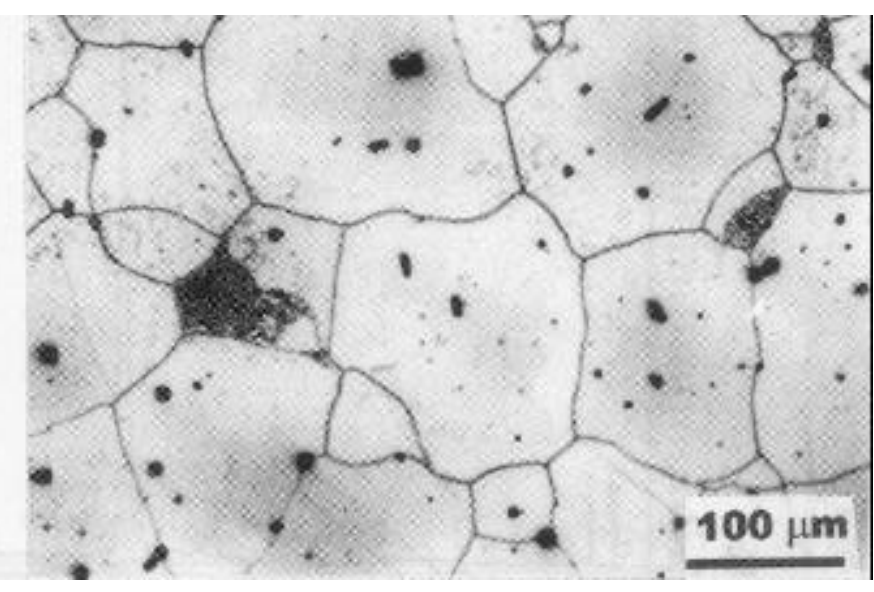

Figure 6. Microstructure of the $\mathrm{Mg}-\mathrm{Al}$ alloy with $\mathrm{Pb}$ showing reduced DP nodules (aged at $523 \mathrm{~K}$ for $4 \mathrm{~h}$ ). 


\subsection{Comments on Meyrick's hypothesis}

As per Meyrick's hypothesis, the addition of $\mathrm{Pb}$ should not affect DP, however, the experimental results of volume fraction transformed and velocity of DP nodules have been suppressed. This is in contradiction to the hypothesis and thus the hypothesis cannot be validated.

\subsection{Calculation of misfit strain parameter}

As it was stated that the Meyrick's hypothesis is not valid, it is necessary to calculate the misfit strain to understand whether there are any changes so that DP can be explained. Further, to the above experimental observations

Table 2. Size and velocity of DP nodules.

\begin{tabular}{lcc}
\hline Condition & $250^{\circ} \mathrm{C}$ for $2 \mathrm{~h}$ & $250^{\circ} \mathrm{C}$ for $4 \mathrm{~h}$ \\
\hline $\begin{array}{l}\text { GA9 without } \mathrm{Pb}, \\
\text { max. nodule size }\end{array}$ & $4.59 \mu \mathrm{m}$ & $9.18 \mu \mathrm{m}$ \\
$\begin{array}{l}\text { GA9 with } \mathrm{Pb}, \\
\text { max. nodule size }\end{array}$ & $2.04 \mu \mathrm{m}$ & $3.57 \mu \mathrm{m}$ \\
$\begin{array}{l}\text { Velocity without } \mathrm{Pb} \\
\text { Velocity with } 0.9 \% \mathrm{~Pb}\end{array}$ & $6.375 \AA / \mathrm{sec}$ & $6.375 \AA \mathrm{sec}$ \\
\hline
\end{tabular}

Table 3. EDX results on the DP nodule.

\begin{tabular}{llrc}
\hline Sl. no. & \multicolumn{1}{c}{ Location } & $\begin{array}{c}\text { Aluminium } \\
\text { (At.\%) }\end{array}$ & $\begin{array}{c}\text { Lead } \\
\text { (At.\%) }\end{array}$ \\
\hline 1. & Matrix & $10 \cdot 01$ & $0 \cdot 21$ \\
2. & Depleted matrix in the nodule & 7.62 & $0 \cdot 16$ \\
3. & Precipitate & $10 \cdot 35$ & $0 \cdot 23$ \\
\hline
\end{tabular}

with regard to reduction of volume fraction transformed and growth velocity of DP nodules, the misfit strain parameter calculations are shown below.

$$
\delta_{\mathrm{th}}=\eta_{\mathrm{Al}}(C s-C o)_{\mathrm{Al}}+\eta_{\mathrm{Pb}}(C s-C o)_{\mathrm{Pb}},
$$

where $\delta_{\text {th }}$ is the theoretical coherency strain parameter, $\eta_{\mathrm{Al}}, \eta_{\mathrm{Pb}}$, the fractional change in lattice parameter with composition $X, C s$, the composition in the frontal diffusion layer, $\mathrm{Co}$, the bulk matrix composition.

Calculations are based on volume since $\mathrm{Mg}$ is hexagonal close packed with lattice parameters $a$ and $c$.

$$
\begin{aligned}
& \eta_{\mathrm{Al}}=\frac{1}{3} \frac{1}{V_{\text {unit cell }}}\left(\frac{\mathrm{d} V}{\mathrm{~d} x}\right)_{\mathrm{Al}}, \\
& \eta_{\mathrm{Pb}}=\frac{1}{3} \frac{1}{V_{\text {unit cell }}}\left(\frac{\mathrm{d} V}{\mathrm{~d} x}\right)_{\mathrm{Pb}}, \\
& V_{\text {unit cell }}=\text { volume of unit cell }=0.866 a^{2} c .
\end{aligned}
$$

Since $a$ and $c$ are functions of $X$ (solute concentration in the matrix), by Vegard's law, differentiating $V$ w.r.t. $x$ of (4)

$$
\left(\frac{\mathrm{d} V}{\mathrm{~d} x}\right)=0 \cdot 866 a\left(2 c \frac{\mathrm{d} a}{\mathrm{~d} x}+a \frac{\mathrm{d} c}{\mathrm{~d} x}\right) .
$$

For $\mathrm{Al}$ in $\mathrm{Mg}$ (Pearson 1958)

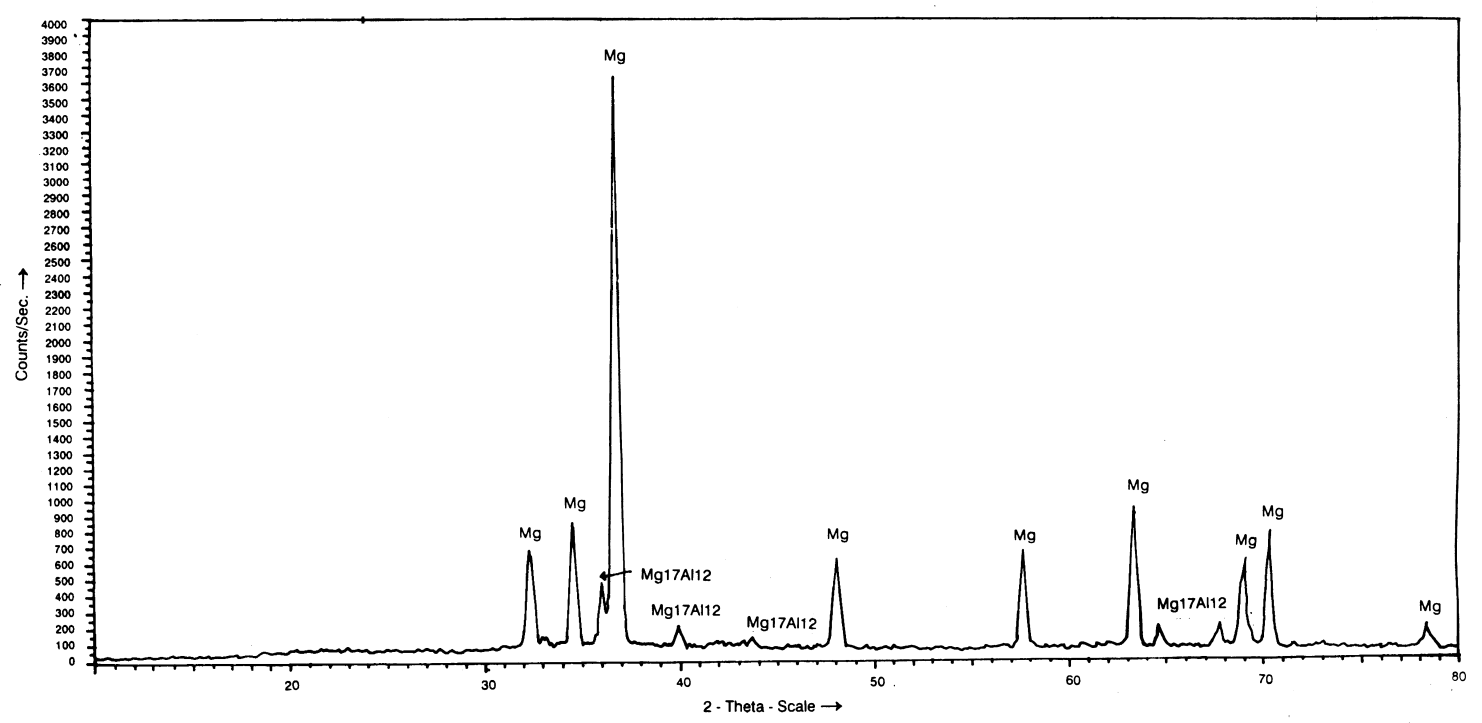

Figure 7. X-ray diffraction pattern of the sample without $\mathrm{Pb}$. 


$$
\begin{aligned}
& \left(\frac{\mathrm{d} a}{\mathrm{~d} x}\right)_{\mathrm{Mg} / \mathrm{Al}}=-0 \cdot 003934 \AA / \mathrm{at} \%, \\
& \left(\frac{\mathrm{d} c}{\mathrm{~d} x}\right)_{\mathrm{Mg} / \mathrm{Al}}=-0 \cdot 00533 \AA / \mathrm{at} \% .
\end{aligned}
$$

For $\mathrm{Pb}$ in $\mathrm{Mg}$ (Pearson 1958)

$$
\begin{aligned}
& \left(\frac{\mathrm{d} a}{\mathrm{~d} x}\right)_{\mathrm{Mg} / \mathrm{Pb}}=0 \cdot 001277 \AA / \mathrm{at} \%, \\
& \left(\frac{\mathrm{d} c}{\mathrm{~d} x}\right)_{\mathrm{Mg} / \mathrm{Pb}}=0 \cdot 00522 \AA / \mathrm{at} \% .
\end{aligned}
$$

Taking

$$
\begin{gathered}
a=3 \cdot 2025 \AA, c=5 \cdot 20 \AA \text { for } \mathrm{Mg}, V_{\text {unit cell }}=46 \cdot 185 \AA^{3}, \\
\left(\frac{\mathrm{d} V}{\mathrm{~d} x}\right)_{\mathrm{Al}}=-0 \cdot 1598 \AA^{3} / \mathrm{at} \% \\
\left(\frac{\mathrm{d} V}{\mathrm{~d} x}\right)_{\mathrm{Pb}}=-0 \cdot 08325 \AA^{3} / \mathrm{at} \% .
\end{gathered}
$$

Substituting (10) to (12) in relations (2) and (3) approximately, we get

$$
\eta_{\mathrm{Al}}=-0 \cdot 001533 / \mathrm{at} \%
$$

$$
\eta_{\mathrm{Pb}}=0 \cdot 0006008 / \mathrm{at} \%
$$

Scanning electron micrographs show DP nodule at high magnification for alloy without $\mathrm{Pb}$ (figure 9a) and with $0.9 \% \mathrm{~Pb}$ (figure $9 \mathrm{~b}$ ), respectively.

Careful EDX analysis was carried out on the DP nodule i.e. the precipitate, $\alpha^{\prime}$ phase (depleted matrix) and the bulk matrix. Table 3 shows the compositions of these three regions, respectively. Figures 10-12 show the EDX patterns of the precipitate depleted matrix and the bulk matrix, respectively.

From these results (table 3 ), the partitioning of $\mathrm{Al}$ and $\mathrm{Pb}$ in the nodule can be obtained.

The concentration of $\mathrm{Al}$ and $\mathrm{Pb}$ in the frontal diffusion layer is assumed to be equal to the concentration in the depleted matrix in the DP nodule.

Thus,

$$
\begin{aligned}
& \left.\begin{array}{l}
C s=7.62 \text { at } \% \\
C o=10.01 \text { at } \%
\end{array}\right\}, \\
& \left.\begin{array}{l}
C s=0.16 \text { at } \% \\
C o=0.21 \text { at } \%
\end{array}\right\} .
\end{aligned}
$$

Substituting the values obtained in (13) to (16) in relation (1), we get

$$
\begin{aligned}
& \delta_{\mathrm{th}}=-0.001533(7 \cdot 62-10 \cdot 01)+0.0006008(0 \cdot 16-0 \cdot 21), \\
& \delta_{\mathrm{th}}=0.00366-0.00003004, \\
& \delta_{\mathrm{th}}=0.00362996 .
\end{aligned}
$$

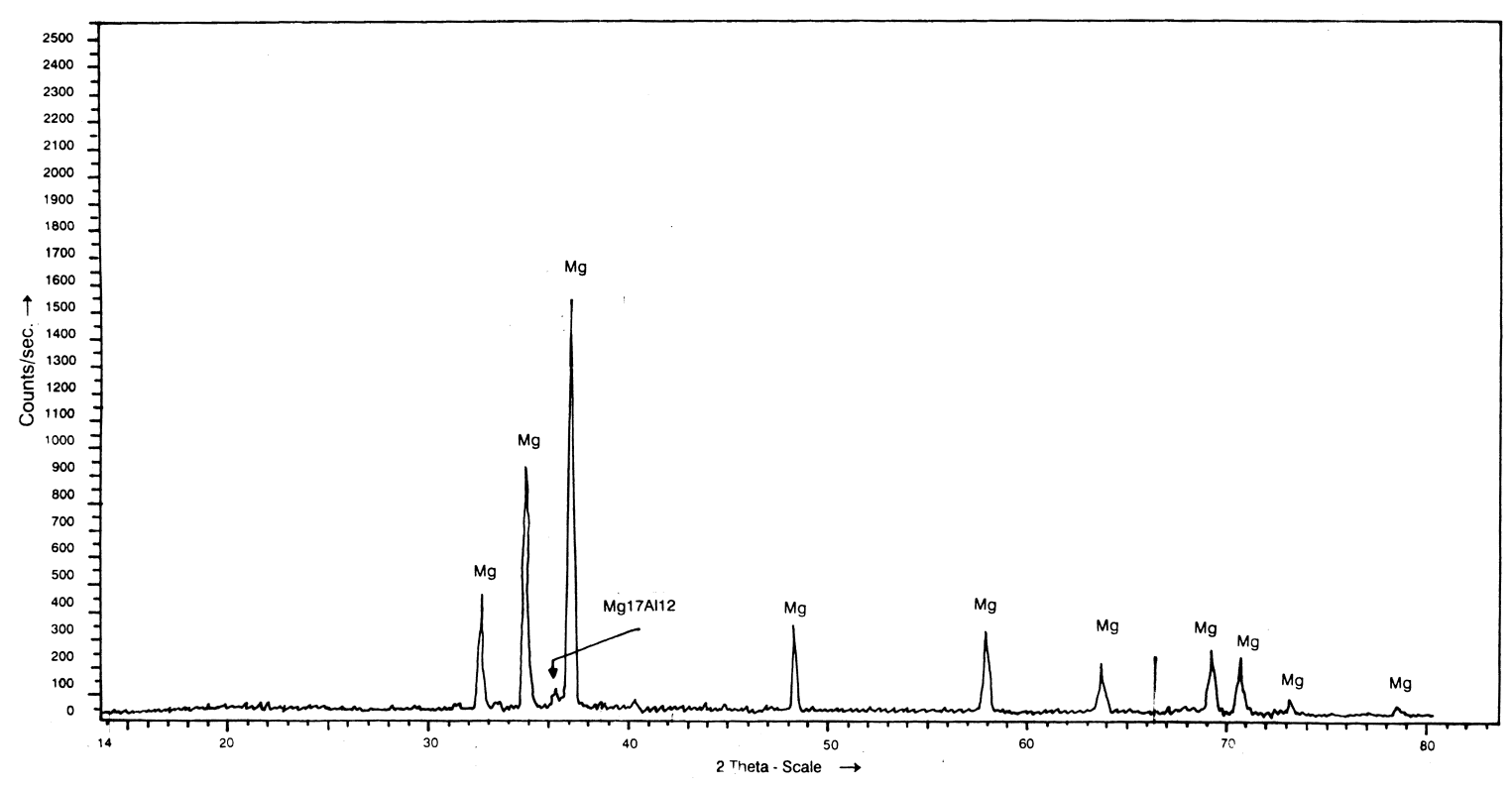

Figure 8. X-ray diffraction pattern of the sample with $0.9 \% \mathrm{~Pb}$. 

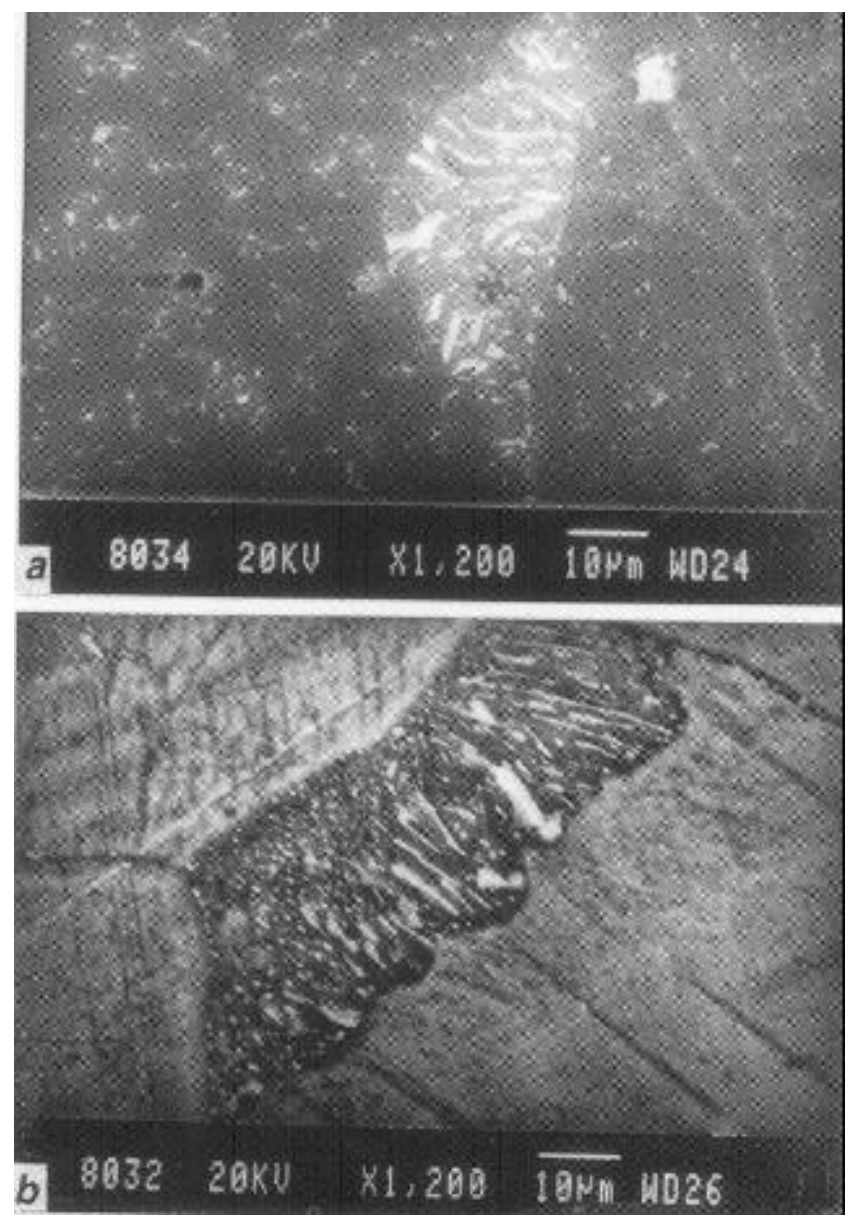

Figure 9. $\mathrm{SEM}$ of $\mathrm{DP}$ nodule for $\mathrm{Mg}-\mathrm{Al}$ alloy without $\mathrm{Pb}(\mathbf{a})$ and with $\mathrm{Pb}(\mathbf{b})$.

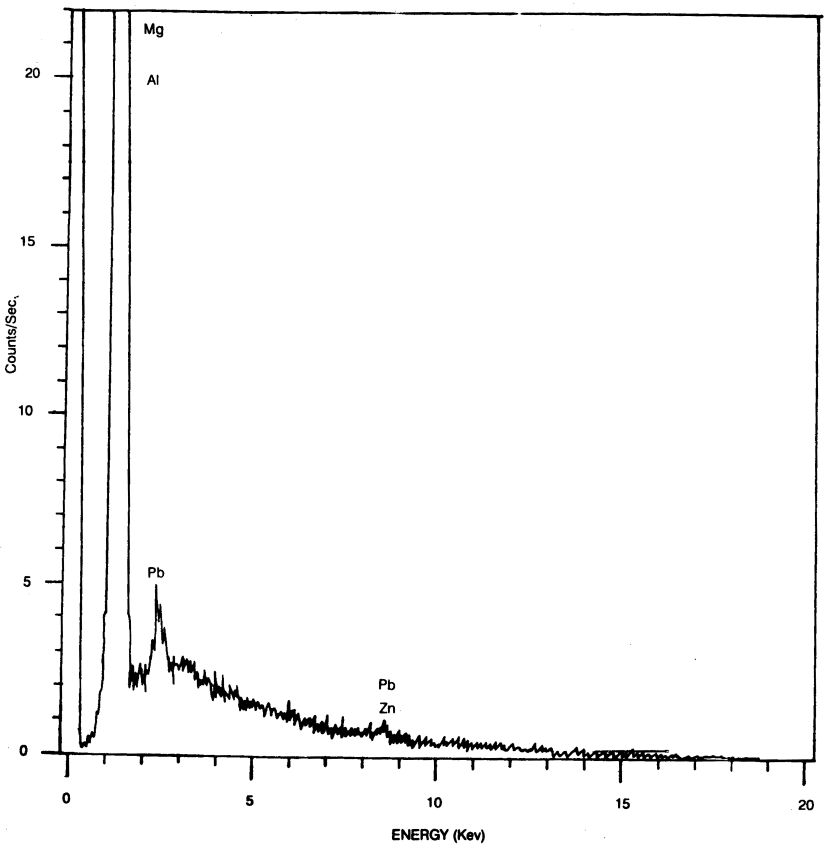

Figure 10. EDX pattern of the precipitate in DP nodule.
The first term on the RHS of the relationship for $\delta_{\text {th }}$ (i.e. (1)) is

$$
\delta_{\text {th }} \text { with Al only }=0.00366 \text {. }
$$

It is seen that $\delta_{\text {th }}$ drops from 0.00366 to 0.00362996 with $0.9 \mathrm{wt} \% \mathrm{~Pb}$ in the alloy, thus $\approx 1 \%$ change showing that the diffusional coherency strain is reduced with addition of $\mathrm{Pb}$ to the alloy. With the reduction in diffusional

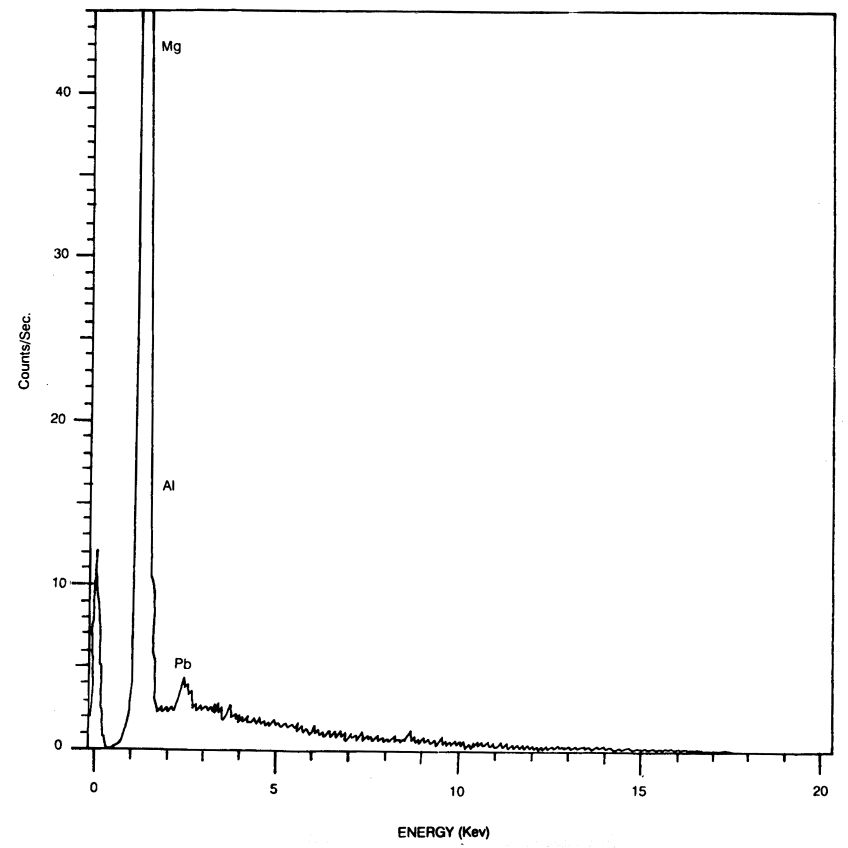

Figure 11. EDX pattern of the depleted matrix in the DP nodule.

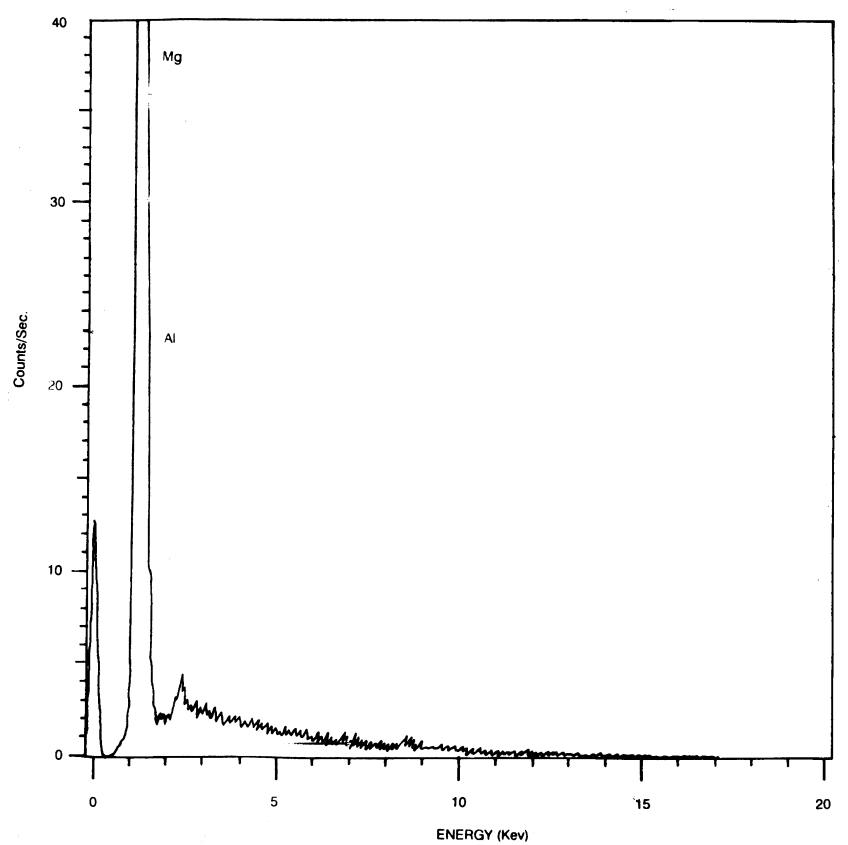

Figure 12. EDX pattern of the bulk matrix. 
coherency strain, the fraction transformed and velocity of DP nodules should decrease as can be seen in figures 3-6 and table 2 .

The above results can be used as evidence for diffusional coherency strain theory in the discontinuous precipitation in $\mathrm{Mg}-\mathrm{Al}$ alloy.

\subsection{Analysis of the results}

From the above results, it can be seen that the volume fraction transformed, the growth velocity of DP and the misfit strain values have reduced on addition of $\mathrm{Pb}$ to $\mathrm{Mg}-\mathrm{Al}$ alloy indicating suppression of DP. Thus, this suppression of DP is attributed to the reduction of coherency strains ahead of moving grain boundary with the addition of $\mathrm{Pb}$ as postulated in para 1 of $\S 3.1$ above.

\section{Conclusion}

Diffusional coherency strain in the frontal diffusion layer ahead of the grain boundary is responsible for discontinuous precipitation in $\mathrm{Mg}-\mathrm{Al}$ alloy.

\section{Acknowledgement}

The authors would like to thank the management of Hindustan Aeronautics Ltd. for constant encouragement and support in carrying out this work.

\section{References}

Baik Y J and Yoon D N 1986 Acta Metall. 342039

Baluffi R W and Cahn J W 1981 Acta Metall. 29493

Chung Y H, Shin M C and Yoon D W 1992 Acta Metall. 40 2177

Fournelle R A and Clark J B 1972 Metall. Trans. 32757

Hillert M and Purdy G R 1978 Acta Metall. 26333

Hillert M 1983 Scr. Metall. 17237

Meyrick G 1976 Scr. Metall. 10649

Pearson W B 1958 A handbook of lattice spacings and structures of metals and alloys (New York: Pergamon Press) 2 p. 1967

Rhee W H, Song Y D and Yoon D W 1987 Acta Metall. 3557 Smithels Metals Reference Book 1983 (UK: Butterworths) 6th ed. pp 11-333

Sulonen M S 1960 Acta Metall. 8669

Sulonen M S 1964 Acta Metall. 12748

Yoon D N and Hupman W S 1981 Acta Metall. 27973 